

\title{
CONTENTS
}

Letters/Release of Ngugi Wa Thiong'o . . . . . . . . . . . 1

Special Announcements .................. . . . . . . . . . . . .

Auditor's Report . . . . . . . . . . . . . . . . . . 6 6

Minutes/Meeting of the Board of Directors . . . . . . . . . . 8

Candidate's Statements .................. . . .

Government Evaluation of Research Projects in Some

Southern African States . . . . . . . . . . . . . . . 10

Letter/U.N. Council for Namibia . . . . . . . . . . . . . 11

Meetings-Past \& Future . . . . . . . . . . . . . 13

Grants and Awards . . . . . . . . . . . . . . 15

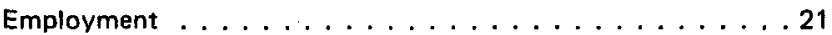

Letter from Richard Moose, Assistant Secretary of

State for Africa, on Carter Administration Policy

in Southern Africa . . . . . . . . . . . . . . . . 23

Visiting Fulbright Lecturers and Researchers in the

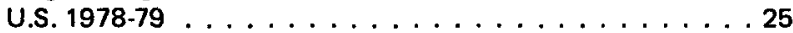

Employment Addenda . . . . . . . . . . . . . . 26

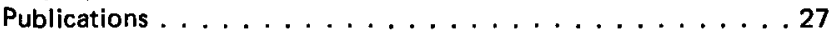

\section{LETTERS/THE RELEASE OF NGUGI WA THIONG'O}

The Editor

8 December 1978

The Daily Nation

Nairobi, Kenya

Dear Sir,

The prison gates have opened in Kenya. Tired compatriots, long behind bars, have stumbled out into the broad daylight of freedom. I congratulate President Daniel arap Moi on this new move to consolidate freedom and democracy in Kenya.

Let me first speak as a Kenyan. I am proud of this latest mood in the country. There is something fresh in the atmosphere.

Let me secondly speak as a Vice-President of the International Congress of African Studies, whose world assembly has just concluded in Kinshasa. The news of the release of political detainees in Kenya broke when the Worid Congress was still in session in Zaire. I was able to report to many delegates in Kinshasa who had expressed anxieties about intellectual and cultural freedom in Kenya that a new leaf had just been turned with the release of such figures as Ngugi wa Thiong'o and Martin Shikuku. 
Thirdly, I would like to speak as the president of the African Studies Association of the United States. This is the largest association of Africanists outside Africa. The Association not only has a Kenyan president for the first time, but has always had many friends of Kenya among its members. I hope to report to my members on my return to the United States that Kenya has happy prospects under Mr. Moi's leadership, especially following the release of political detainees.

Yours sincerely,

Ali A. Mazrui, D. Phil., (Oxon)

Professor of Political Science and

Director of Afroamerican and African Studies

The University of Michigan, Ann Arbor

The Editor

18 December 1978

The Standard

Nairobi, Kenya

Dear Sir,

$I$ arrived in Kenya in the week in which our government, under the leadership of President Daniel arap Moi, released all political prisoners. Although my loyalty to Kenya has never wavered, I have felt extra-proud this last week. Once again Kenya is setting an admirable example to other societies.

African countries need to learn from each other. There are countries in our continent that could teach us a thing or two about economic morality and self-discipline. There are others that have contributed more to the liberation of Southern Africa than we have.

But $\sqrt{ }$ do not believe there is any African country that can teach us much about political toleration and openness so far. All our neighbours have been guilty of greater democratic lapses than we have over the years. Most of our neighbours continue to have many political prisoners.

But there is no room for complacency in Kenya. It is indeed true that the price of freedom is eternal vigilance. We may have done better than our neighbours so far-but we must strive to excell ourselves!

In his first few months in office our president has emerged as "Moi, the Merciful"! He has set himself high standards across the horizons. The stars are watching. I wish our captain Bon voyage!

Ali Mazrui, D. Phil., (Oxon)

Professor of Political Science and

Director of Afroamerican Studies

The University of Michigan, Ann Arbor

TO WHOM IT MAY CONCERN:

January, 1979

I was in Kenya in the week in which Ngugi wa Thiongo'o was released. I visited him on his farm not too far from Limuru. He had been in detention for nearly a year. Seeing him again as a free man was indeed a memorable experience. I bore witness to a restoration.

While in detention Ngugi had not realized the magnitude of the international campaign for his release. He seemed genuinely moved to learn about its scale. He asked me to thank those that had been so concerned about his fate. There are too many to thank individually. Yet Ngugi was also reluctant to do it through a letter to the Press (even if The Times of London was still publishing, which of course it was not!l!). So if you know of others, like yourself, who shared the international anxiety about the fate of this important artist, please convey to them the writer's genuine gratitude and appreciation. A little bit of our own freedom dies whenever a creative intellect is silenced. Your solidarity behind Ngugi helped to ensure that the voice of this particular mind was not silenced but temporarily muffled.

What were Ngugi's future plans when I met him? He needed peace and quiet for a while. In detention he had "quiet"- but no prisoner against his will has peace. The new tranquility of his farm, the warmth of his family, and the reassuring welcome of his neighbors, were the beginning of a sense of restoration.

Physically he looked well-virtually like his old self, in spite of the prison dietl He also joked and laughed like his old self. The students of the University of Nairobi had given him a tumultuous welcome back to freedom. Yes, it was good to be back.

Thank you again for closing ranks in defence of this man.

Yours sincerely, Ali Mazrui

President, African Studies Association 